\title{
Interculturalismo \& reconhecimento da diferença: reconstruindo os direitos humanos no itinerário dos apátridas e refugiados*
}

\section{Interculturalism \& recognition of difference: human rights in reconstructing the routeof stateless persons and refugees}

\section{Resumo}

A concepção tradicional dos Direitos Humanos é ancorada por premissas que já não conseguem dar conta da crise de sentido a qual atravessa as relações mundanas, principalmente no panorama internacional, no que tange aos apátridas e refugiados. Dentre tais premissas, destacamos, na primeira parte deste artigo, a ideia de "nacionalidade" e a pretensão "universalista" dos Direitos Humanos como representações emblemáticas do esgotamento desta compreensão tradicional. Na segunda parte, desenvolvemos a percepção interculturalista como alternativa ao modelo tradicional, avessa a perspectiva da "identidade pura", que a ficção da nacionalidade dá vazão. A nova perspectiva tem como ponto de partida o reconhecimento da diferença e não a padronização da igualdade como premissa para se repensar os Direitos $\mathrm{Hu}$ manos.

Palavras-chave: Direitos Humanos. Apátridas. Refugiados. Nacionalismo. Universalismo. Interculturalismo. Reconhecimento da diferença.

\begin{abstract}
The traditional conception of human rights is rooted in assumptions can not carry with the crisis of meaning which crosses the worldly relations, especially in the international arena with regard to stateless persons and refugees. Among these assumptions, we highlight in this article the idea of "nationality" and the pretention "universal" of human rights as iconic representations of the exhaustion of this traditional understanding. In the second part of the article, the perception interculturalist developed as an alternative to the traditional model, adverse terms of "pure identity", that fiction gives way to nationality. The new perspective has as its starting point there cognition of difference and not the standards of equality as a premise to rethink human rights.
\end{abstract}

Key-words: Human Rights. Stateless persons. Refugees. Nationalism. Universalism. Interculturalism. Recognition of difference.

* Recebido em 29/09/2011

1 Doutorando em Filosofia pela PUC/RS, Mestre em Direito pela UNISINOS, Especialista em Ciências Penais pela PUC/RS, professor de Teoria do Direito da Uniritter Laureate International - Porto Alegre/ Canoas. E-mail: gustavo_pereira@uniritter.edu.br 


\section{Introdução}

A afirmação dos instrumentos de proteção internacional aos refugiados e apátridas é vasta. Abordaremos, inicialmente e de forma breve, alguns institutos que intentam viabilizar e concretizar a prerrogativa universalista da concepção tradicional de Direitos Humanos, dando atenção ao princípio internacional do "non-refoulement", conhecido como princípio da "não-devolução" ou "nãoretorno".

Vencida a exposição breve dos mecanismos que ancoram as prerrogativas universalistas, denotaremos o seu esgotamento como suporte para o pensamento cosmopolita interculturalista, a partir do reconhecimento da diferença, que trazemos a tona como proposta de reconstrução de sentido para a compreensão dos Direitos Humanos na segunda parte deste artigo, no que afeta ao reconhecimento dos apátridas e refugiados.

A abordagem do presente artigo será interdisciplinar, a partir de uma dimensão crítica. A proposta é colocar em diálogo a Filosofia, a Sociologia, a Antropologia, a Ciência Política, o Direito e as Relações Internacionais para desenvolver um campo especulativo que ponha em discussão algumas das bases da concepção tradicional dos direitos humanos, vislumbrando sua muitas vezes infértil fundamentação teórica, propondo novos rumos de pensamento que não admitem a fixidez de uma resposta acabada.

\section{Os instrumentos de proteção internacional para refugiados e apátridas}

O século XX consagra-se por ser o século dos refugiados (CANÇADO TRINDADE, 1981, p. 145). É bem verdade que, em todas as épocas, os conflitos armados originaram deslocamentos de pessoas com todo o seu cortejo de perseguições e de privações, contudo nunca como no referido momento histórico.

Almeida (2001, p. 162) afirma que a definição ampliada do termo "refugiado" coaduna-se, precisamente, com o significado original da palavra asilo. A ideia seria de oferecer à pessoa, vítima de uma violência, a possibilidade de encontrar uma proteção em um lugar seguro para viver e para fruir sua liberdade. Essencialmente, aquele que busca asilo é, em geral, alguém que está fugindo de uma situação insuportável de violência, em qualquer definição possível do termo.
Após o fim da Liga das Nações e a implementação da Organização das Nações Unidas, cria-se o ACNUR como órgão internacional responsável para tratar a situação do refúgio. O primeiro instrumento que trata dos mecanismos de proteção internacional aos refugiados foi a Convenção de 1951, que descreve o que vem a ser o status de refugiado, em seu artigo primeiro, para o Direito Internacional e como devem se desenvolver os aparatados para sua proteção.

O objetivo da Convenção foi o de proteger as pessoas que estavam sendo perseguidas na Europa em seu país de origem e/ou moradia habitual, em decorrência dos entraves ocorridos na segunda guerra mundial. Dentre os motivos da perseguição, destacam-se os casos que envolvem discriminações raciais, religiosas, étnicas, pertencimento a algum determinado grupo social ou opinião política. Assim, a Convenção estabelece a compreensão do status de refugiado, no âmbito do direito internacional, devendo ser protegido pelo instituto do refúgio todo e qualquer ser humano que esteja sendo perseguido em virtude de sua cor, religião, nacionalidade, opinião política e pertencimento a algum grupo social, diferentemente do asilo, que está limitado apenas a perseguição política (JUBILUT, 2007).

A Convenção também estabelece como princípio norteador para a questão dos refugiados o princípio do "non-refoulement", cuja tradução brasileira foi feita como princípio da "não-devolução". É a partir deste princípio que pretendemos dar início ao processo de ruptura com o modelo tradicional de percepção dos Direitos Humanos.

\section{0 princípio da "não-devolução" (non-refoule- ment)}

O princípio da não-devolução está consagrado pelo artigo 33 da referida Convenção Internacional dos Refugiados, de 1951. O dispositivo prevê que nenhum Estado poderá expulsar um refugiado para as fronteiras dos territórios em que a vida ou a liberdade deste esteja ameaçada em virtude de sua cor, nacionalidade, grupo social ou disposições políticas ou religiosas, desde que este não recaia em uma das cláusulas de cessação ou de exclusão que exploraremos a seguir. O princípio da Não-devolução provém do termo francês "non-refoulement", representando, para o Direito Internacional, a construção da base valorativa dos atos jurídicos que intentam impe- 
dir que determinado Estado devolva um indivíduo que se encontra sob sua jurisdição em busca de refúgio (LUIZ FILHO, 2001, p. 180). Trata-se de coibir a repulsa de um Estado à presença do refugiado em seu território.

Uma breve discussão semântica sobre a tradução do princípio "non-refoulement" para a sua versão em português nos parece pertinente. $\mathrm{O}$ sentido semântico do termo em francês "refoulement" traduz a ideia de "recuo", de "fazer recuar", ou "ação de recusar acesso", segundo a gramática especializada. Outras vezes é também traduzido como "recalque" ou "repressão". Ao que tudo indica, a tradução do termo "refoulement" por "devolução" não soa apropriada. Não é fiel a terminologia francesa nem ao ideal humanitário e cosmopolítico do Direito Internacional.

A ideia de "devolução" contém em sua redoma de significado, de algum modo, um caráter objetificador. Cabe-nos aqui perguntar: o que é passível de devolução? "Devolver" sugere a entrega de algo a alguém. Sugere a situação de um tratamento que se dá a uma "coisa". Devolvemos objetos. Devolvemos dinheiro. Restituímos algo a seu dono; a seu proprietário. Não devolvemos pessoas.

Não-devolver aquele que à mim não é idêntico, $\mathrm{o}$ diferente, o hipossuficiente; restituir um refugiado a seu dono, a seu proprietário, livrar-se dele. Tais proposituras referenciam o sentido oposto à ideia de hospitalidade incondicional, condição primordial para se pensar a possibilidade de um direito cosmopolita.

Toda filosofia é, de algum modo, uma filologia, e o respeito a isso, ao estudo histórico-semântico-pragmático de um signo lingüístico, é fundamental sob qualquer aspecto, ainda mais como o evidenciado na tradução em destaque. Neste sentido, é fundamental o respeito a história semântica do termo. Talvez a tradução mais coerente ao sentido semântico do termo "refoulement" e ao sentido humanitário do Direito Internacional seja como o princípio da "não-recusa", ou como cláusula do "não-retorno", como alguns segmentos da academia internacionalista costuma adotar.

O princípio da "não-devolução", ou "não-retorno", como preferimos traduzir, sem dúvida, estabelece uma das principais diretrizes das Convenções e Tratados Internacionais contra a prática de crimes contra a humanidade no cenário daqueles que procuram proteção internacional. No contexto do Direito Internacional Humani- tário, intenta coibir todas as tentativas que visam a saída compulsória do estrangeiro do território em que pede refúgio. É importante enfatizar que esse princípio, por se encontrar relacionado ao âmbito do Direito Internacional, em tese, detém aplicabilidade para além das regras de direito interno de cada país. Desse modo, o princípio impede o Estado de retornar um refugiado a outro Estado que o persiga, abrangendo a proibição do ente estatal de repelir o refugiado que em seu território busca proteção.

A proibição da devolução aplica-se ao solicitante de refúgio, assim compreendido pelos instrumentos internacionais. Dessa forma, para que não reste prejudicado o princípio em tela, incumbe-se às autoridades imigratórias avaliar as condições de chegada e do país de origem do solicitante de refúgio. Tal mecanismo jurídico se aplica, conseqüentemente, quando há solicitação do reconhecimento da condição jurídica de refugiado, expressa pelo indivíduo estrangeiro. A violação deste princípio se dá no momento da entrada de pessoas nessa condição em dado território nacional. A rejeição da entrada, ainda que não esteja de fato nos limites territoriais do país, mas na fronteira, ainda em solo internacional fronteiriço, implica já a violação do princípio.

O instrumento internacional que confere proteção para toda pessoa considerada sem pátria ${ }^{2}$, ou seja, aquela pessoa que não tem sua nacionalidade reconhecida pela legislação de nenhum Estado, esta regulado pela Convenção sobre o Estatuto dos Apátridas, aprovada em Nova Iorque, em 28 de Setembro de 1954, tendo entrado em vigor em 6 de Junho de 1960, em conformidade com seu artigo $39^{\circ}$.

O Estatuto dos Apátridas, em larga medida, reproduz os preceitos e princípios já estruturados pelo Estatuto dos Refugiados, no âmbito da proteção internacional. O Estatuto tornou o problema da apatridia também de responsabilidade do ACNUR.

Segundo o quadro estatístico divulgado pelo CONARE em junho de 2010, os refugiados de origem africana compõem a maioria da população de refugiados no Brasil, com $64,9 \%$. Em seguida, os refugiados do continente americano (22,3\%), da Ásia (10,3\%) e da Europa $(2,2 \%)$.

\footnotetext{
2 "Artigo 1. ${ }^{\circ}$ Definição do Termo Apátrida: 1 - Para efeitos da presente Convenção, o termo apátrida designará toda a pessoa que não seja considerada por qualquer Estado, segundo a sua legislação, como seu nacional”.
} 
No que tange às nacionalidades, os maiores grupos são formados por angolanos (1.688 pessoas, ou 39,3\% do total), colombianos (589 pessoas - 13,7\%), congoleses (420 pessoas $-9,8 \%$ ), liberianos (259 pessoas $-6 \%$ ) e iraquianos (199 pessoas $-4,6 \%$ ).

No mundo, em 2009, o número de pessoas forçadas a se deslocar em virtude de conflitos e perseguições foi o maior nas últimas duas décadas, totalizando 43,3 milhões em todo o mundo. Esta é a maior cifra de deslocamentos forçados por tais razões desde a metade dos anos 90. Os referidos dados constam no Relatório de Tendências Globais de 2009, divulgado em junho de 2010 pelo ACNUR. No entanto, os índices de deslocamentos voluntários e de refugiados repatriados voluntariamente para seus países de origem caiu ao nível mais baixo em 20 anos.

Há contextos onde a proteção está se tornando mais evasiva para os refugiados, solicitantes de asilo e deslocados internos, onde ONGs desempenham um papel importante em chamar atenção para as necessidades de proteção não correspondidas em situações específicas e identificar tendências globais. Estas atividades e declarações públicas informaram sobre a crise na proteção aos refugiados pelo menos na ultima década (FERRIS, 2003, p. 129).

Em virtude da crescente persistência dos conflitos, mais da metade dos refugiados sob os cuidados do ACNUR estão em situações de refúgio prolongado, permanecendo há mais de cinco anos no exílio.

O relatório do ACNUR mostra que apenas $251 \mathrm{mil}$ refugiados retornaram para casa em 2009. Este é o menor número desde 1990. Na última década, os retornos voluntários totalizavam cerca de 01 milhão, por ano.

No ano de 2009, o número de pessoas deslocadas internamente por conflitos em seus próprios países aumentou $4 \%$, chegando a 27,1 milhões. No mesmo período, o número de novos solicitantes de refúgio no mundo chegou a quase 1 milhão. A África do Sul é o hoje o principal destino de solicitantes de refúgio no mundo. Cerca de 220 mil novos pedidos no ano de 2009. Mas a proteção internacional dos direitos humanos em relação apenas aos apátridas e a situação de apatridia, não retrata tamanha propulsão, como demonstraremos a seguir. Neste instante inaugura-se a vertente crítica que o presente ensaio se propõe.
Aqui começa a advertência crítica que nos propomos a discutir neste artigo. Veremos a seguir que o cerco de proteção internacional, a partir de Tratados e Convenções Internacionais, até os dias atuais, tem seu enfoque muito mais direcionado a proteção no âmbito dos refugiados, pois o artefato primordial, como mecanismo de proteção, está no incentivo ao retorno voluntário do refugiado ao seu Estado-nação. Já o fenômeno da apatridia aparenta estar sempre na espreita da proteção internacional para os refugiados, apesar de existirem Convenções específicas para os seus casos. Isso denota o nível de importância atrelada a ideia de "nacionalidade" como porta de acesso primordial na garantia dos direitos fundamentais, algo reforçado pela compreensão tradicional dos Direitos Humanos, na qual estabelece uma a diferença entre "ser humano" e "cidadão".

\section{A ficção da "nacionalidade"}

A ficção da "nacionalidade" é o emblema da concepção tradicional de direitos humanos que propomos discorrer para corroer e questionar a sua legitimidade como paradigma de fundamentação. Tentaremos demonstrar que a construção fictícia da "nacionalidade" traz conseqüências jurídicas no âmbito da proteção internacional, pois contempla uma ampliação protetiva maior aos refugiados, exatamente por estes deterem uma nacionalidade, do que aos apátridas. Assim, na prática, a situação do apátrida, nesses termos, é pior que dos refugiados, dando margem ao sério problema filosófico que está explicitado pela circunstância de não ter pátria.

Ter pátria significa ter ao menos uma porta de acesso ao direito. A configuração e formatação de toda ideia de estado de direito esta vinculada a ideia de nacionalidade. A "nacionalidade" é uma ficção criada pela humanidade, atrelada a ideia de "cidadania", que surgiu na idade antiga, onde apenas eram considerados cidadãos homens proprietários de terras. Mulheres, crianças, estrangeiros e escravos, por óbvio, não eram considerados cidadãos. Hoje em dia, a ficção da nacionalidade é o vínculo jurídico de direito público interno entre uma pessoa e um Estado. Esta ficção aborda a ideia de que a simples condição do nascimento confere nacionalidade à alguém. Jacques Derrida (1994, p. 123) percebe que "não existe nacionalidade, ou nacionalismo, que não seja mitológico, digamos em sentido amplo, "místico"'. 
A artificialidade da nacionalidade, nos parâmetros atuais, se dá pelas ficções jurídicas estabelecidas pelos critérios do jus solis e do jus sanguinis. Assim, um país poderá reconhecer a nacionalidade de uma pessoa (e consequentemente sua cidadania e seu ingresso no estado de direito) pelo critério do território, ou seja, pelo nascimento em solo nacional; ou pelo critério do sangue, ou seja, em virtude da filiação, sendo o local de nascimento irrelevante para essa regra. Alguns países atenuam a regra principal e estendem seu critério para conceder cidadania a algumas pessoas, em casos isolados.

A apatridia muitas vezes se dá pela concorrência negativa entre os critérios fictícios do jus solis e do jus sanguinis. Por exemplo, o filho de um casal, que em seu Estado tem sua cidadania reconhecida pelo critério do solo, gerado em um país que reconhece nacionalidade pelo critério do sangue, será um apátrida.

Outra forma de aquisição da nacionalidade se dá pela "naturalização". A naturalização é um modo derivado de reconhecimento da cidadania, que ocorre quando um país concede a qualidade de nacional a um estrangeiro que a requeira. É uma forma de adquirir uma nacionalidade diversa da nacionalidade de origem. Importante notar que a "naturalização" não tem nada de natural. É a aquisição da cidadania pela artificialidade. É a própria e pura expressão de que a nacionalidade é uma ficção.

Poderia se argumentar que a "nacionalidade" fora inventada para, nada mais, nada menos, estabelecer critérios de organização interna entre os súditos de determinada soberania. No entanto, o último século demonstrou que a ficção da nacionalidade é capaz estruturar barreiras definitivas entre nações e disseminar ódio e repulsa do cidadão nacional perante o estrangeiro. $\mathrm{O}$ orgulho da nacionalidade muitas vezes representa a legitimidade para neutralizar e excluir o diferente ${ }^{3}$.

\footnotetext{
3 Há de se atentar que, em verdade, a discussão sobre a questão do nacionalismo é, por si só, de demasiada complexidade, ensejando um artigo independente para realmente dar conta das suas infindáveis nuances. Neste sentido, anoto e remeto ao leitor à obra de Benedict Anderson que, com envergada propriedade e riqueza de detalhes, contextualiza a história da relação "nacionalidade" e Estado-nação", até mesmo para bem além do horizonte ocidental, contextualizando a formação das identidades no Japão, China e no continente africano dentre outros. (ANDERSON, 1993, p. 135 - 147).
}

Ser reconhecido como cidadão de um país é ter o seu valor humano reconhecido. A cidadania hoje tem valor de mercado. Algumas valem mais, muito mais que outras. Por isso não é de se estranhar a situação de pessoas dispostas a entregar algum órgão do seu corpo apenas humano no mercado negro europeu em troca de um green card, ou comprar casamentos para tornar legal e bemvinda sua permanência em determinado país.

A aquisição da cidadania estadunidense também pode representar um bom negócio tanto para os Estados Unidos quanto para os estrangeiros que buscam lá a cidadania. Em 1990, os Estados Unidos lançaram o programa de concessão de "visto de investidor" (o EB-5), projetado para estimular a economia do país, atraindo estrangeiros com capacidade de injetar grandes quantias de dinheiro e criar novos postos de trabalho. São fornecidos 10 mil vistos todos os anos para investidores, incluindo familiares e dependentes. Em 2011, o montante de dinheiro necessário a ser investido para ser reconhecida a cidadania foi reduzido de um milhão de dólares para 500 mil dólares.

É notório que a vinculação a uma cidadania é algo demasiadamente precioso para alguém presente na Europa. Ser um apátrida em solo europeu pode representar a maior ameaça a sua vida. Ter em seu favor apenas a vida, o mero status de ser humano, pode representar o maior de todos os riscos de vida. Neste sentido, Hannah Arendt, ao analisar o desenvolvimento da apatridia na Europa no período das guerras mundiais, em aguda perquirição, percebeu que aqueles que perderam a nacionalidade estavam entregues a sua mera vida. Apenas contavam com sua própria humanidade e isso não significou que estariam protegidos, pois estavam os Estados soberanos reconheciam esta humanidade, sem reconhecer-lhes direitos. Por esse motivo, os apátridas, nesse contexto histórico, perambulavam pelas ruas sem ter o respaldo ou proteção dos países em que se situavam, chegando ao ápice de terem que cometer pequenos delitos para, enfim, terem direito a cama, alimentação e auxílio jurídico com a sua prisão.

A mera vida, ou a mera dignidade em abstrato, não representou qualquer amparo ao apátridas e refugiados na circunstância denunciada por Arendt. Esta percepção denota o fracasso das concepções, sejam elas naturalistas ou racionalistas, que reverenciam os direitos humanos a uma suposta existência de um "ser humano em si", domado pela sua essência, pois este homem puro, como vimos, 
perdeu todas as suas qualidades especificas e relacionais ao se tornar um ser meramente humano.

O conceito de direitos humanos [...] desmoronou no mesmo instante em que aqueles que diziam acreditar nele se confrontaram pela primeira vez com seres que haviam realmente perdido todas as outras qualidades e relações específicas - exceto que ainda eram humanos. O mundo não viu nada de sagrado na abstrata nudez de ser unicamente humano (ARENDT, 1990, p. 333).

Esta afirmação confirma a insuficiência da abstração conceitual “dignidade da pessoa humana” em um âmbito onde ter a dignidade meramente reconhecida, sem que isso implique alguma relação prática ao universo das relações, acaba soando como um mero adorno retórico e uma saída tangencial que não abarca a profundidade do problema. Não podemos falar em "dignidade" como uma categoria de essência atribuída a todos os homens na terra, por mais nobre que essa ideia nos possa parecer ${ }^{4}$.

A ficção da nacionalidade é o emblema determinante dos direitos humanos, e exatamente por isso, representa o seu ponto sego, pois os instrumentos de proteção internacional não conseguem em lidar com a figura do ser humano que não detém nacionalidade ou que perdeu a nacionalidade, ou seja: o apátrida.

O refugiado argelino, o refugiado colombiano ou o refugiado angolano, por mais que sua situação de refugiado represente um grave perigo a sua existência, ainda assim contam com uma certa "identidade", gerada pela ficção da nacionalidade, perante os órgãos de proteção internacional. Poderá, com sorte, em breve ser repatriado voluntariamente. A Declaração Universal dos Direitos Humanos aponta, em seu artigo XV, que "todo homem tem direito a uma nacionalidade", denunciando a importância que internacionalmente se dá a ficção da nacionalidade, tornando ela o elo legal que há entre o Estado e o indivíduo. E qual o motivo disso? Por que ser declarado cidadão de um país me concede o ingresso ao estado de direito? Por que ser considerado apenas um ser humano não é o bastante para me retirar do limbo jurídico? Tais questões serão perquiridas em breve.

4 Não teremos espaço aqui para esmiuçar o argumento. Assim, remeto o leitor o nosso "A pátria dos sem pátria: direitos humanos \& alteridade” (PEREIRA, 2011, p. 59-89) para obter uma análise mais acurada.
Em decorrência da dificuldade de se garantir proteção internacional aos apátridas, em 1961, a Organização das Nações Unidas proclamou a Convenção para redução dos casos de apatridia, deixando clara a dificuldade de conferir assistência para as pessoas consideradas sem pátria. Em 2010, antecipando a comemoração ao $50^{\circ}$ aniversário da referida convenção, o ACNUR lançou a Campanha das Convenções sobre apatridia, convocando os Estados a aderir a esta Convenção, bem como a Convenção de 1954 sobre o Estatuto dos Apátridas, tentando proporcionar um sentimento de cooperação internacional.

No entanto, o número de países que aderiram à convocação no intuito de eliminar o fenômeno da apatridia ainda não é expressivo. Mesmo nos casos onde os países aderem as Convenções internacionais, tal fato ainda não significa a efetiva concretização dos pactos humanitários. A violação aos Tratados Internacionais assinados, na maioria dos casos, não resulta em punição aos países que os violam. A censura aos países violadores dos pactos internacionais muitas vezes se dá apenas em nível simbólico, tornando-se público perante a imprensa internacional a violação de direitos humanos praticada por tal Estado, para constrangê-lo perante a comunidade mundial.

No âmbito dos apátridas e refugiados, todos os litígios que envolvem a violação da Convenção de 1951 são da competência da CIJ (Corte internacional de Justiça), principal órgão judiciário da Organização das Nações Unidas, com sede em Haia, nos Países Baixos. Porém, a averiguação da Corte depende da denúncia de algum país signatário ao pacto. Isso muitas vezes se torna uma moeda política entre os países, resultando em absoluta inocuidade.

Conforme aqui se sustenta, não é de se espantar o apresso dado à nacionalidade, uma vez que ela é quem garante o acesso ao reconhecimento de direitos. Não ter pátria significa ter apenas a simples vida natural. Algo que, para fins práticos, representa o limbo jurídico, onde nenhum Estado-Nação poderá ser, efetivamente, responsabilizado por qualquer afronta às garantias fundamentais dos apátridas, como também, e não menos importante, ser responsabilizado pela total indiferença conferida a eles.

Como já referimos anteriormente, uma das mais louváveis tentativas de abarcar a atuação dos órgãos internacionais de proteção, no âmbito do Direito Humanitário Internacional, está no princípio "non-refoulement", já mencionado anteriormente. 
No entanto, esta cláusula de não-retorno está recepcionada juridicamente apenas na Convenção que trata a questão dos refugiados, em seu artigo 33. Não há previsão legal no Estatuto dos apátridas, demonstrando o quanto a questão da nacionalidade é decisiva no cerco da proteção internacional.

Com a ausência do princípio, estaria o Estado, juridicamente falando, impedido de devolver ao país originário do conflito aquele que advém em busca de proteção em seu território apenas na condição de refugiado. Já o apátrida poderia ser retornado ao país de onde veio sem o Estado ferir sua Convenção, que não contemplou o princípio da "não-devolução", ou o princípio do "não-retorno" como preferimos chamar, em seu corpo de regras. Este fato demonstra que os Tratados e Convenções Internacionais, bem como a referida campanha da ONU, convocando os países para discutir ferramentas para diminuir a insurgência do fenômeno da apatridia, denotam muito mais um apelo a boa vontade de alguns seres humanos do que um sistema de regras que vinculam os Estados signatários a aplicar.

Agora é chegado o momento de ampliar o grau de complexidade que o problema aqui enfrentado demanda. É chegado o momento de expor como os instrumentos de proteção internacional, em seu momento decisivo, muitas vezes não tem aplicabilidade satisfatória, demonstrando a crise da eficácia dos direitos humanos. A partir dos exemplos empíricos e dos dados que apresentaremos passa a se tornar irrelevante distinguir "apátridas" de "refugiados", pois ambos passam a habitar o corpo biopolítico, experienciando na carne a figura da vida sem direitos, tendo a todo o instante suas sobrevivências ameaçadas.

Arendt (1990, p. 314), afirma que a diferenciação entre apátridas e refugiados se dá pelo primeiro se caracterizar pelo fato de não ter nacionalidade enquanto o segundo é determinado por ter perdido a proteção diplomática. Entretanto, esclarece que para fins práticos na maioria dos casos esta diferença é irrisória, pois todos os refugiados, de algum modo, são apátridas na esfera política. Esta aproximação também é apropriada nos dias atuais.

A partir disso, teremos como pressuposto de que a ficção da "nacionalidade" e a concepção "universalista”, presentes na concepção tradicional de se pensar os
Direitos Humanos, representam sérios obstáculos para a configuração de um direito cosmopolita, ou seja, para a construção de uma respeitabilidade global da diferença cultural entre os seres humanos; - mais que isso: pelo respeito a singularidade do outro como totalmente outro-, para bem além do mero artifício da tolerância entre soberanias (ao que parece ser o último argumento em ternos de ciência política) e para bem além do mero procedimentalismo nos quais estão contaminadas as concepções jurídicas de ontem e de hoje, que entendem que a simples positivação de Tratados e Convenções internacionais são suficientes para dar conta da crise de sentido nas quais as relações humanas se deparam hoje em dia. A desconstrução desses elementos é uma estratégia fundamental para reescrever os direitos humanos no itinerário dos apátridas e refugiados.

A ideia de nacionalidade supõe uma concepção da identidade de um povo, de uma pureza étnica, que em muitos casos leva ao ódio e a repulsa a diferença. Em nosso entender, esse é um dos maiores problemas enfrentando pelos apátridas e refugiados: A ameaça da diferença. O medo de reconhecer a diferença daquele que vem de outra pátria ou de pátria nenhuma. O medo de chocar-me com outra cultura.

A reposta da concepção tradicional de direitos humanos a este problema se dá a partir de um "universalismo", sem perceber que, na prática, este universalismo institui muito mais uma forma de padronização do mundo. É pela ótica dos países que representam a elite internacional, ou seja, as potências da econômica mundial, que se dita a sua cultura que deve ser "universalizada".

O universalismo dos direitos humanos e a cultura da nacionalidade retroalimentam os ideais de pureza e de patriotismo exacerbado que, em nossa ótica, simbolizam, dentre outros que aqui não iremos nos ater, o problema de paradigma dos direitos humanos. Passamos agora a desenvolver essa ideia.

\section{Identidade e etnocentrismo: rediscutindo as bases do patriotismo e do culto a pureza cultural}

Nunca houve um monumento da cultura que não fosse também um monumento da barbárie. E, assim como a cultura não é isenta de barbárie, não o é, tampouco, o processo de transmissão da cultura. (BENJAMIN, 1996, p. 225) 
A discussão em torno da questão da formação de identidades e do nacionalismo gerado a partir da ideia de Estado-nação denota uma expressa complexidade na qual devemos de antemão atentar. Inúmeros autores debatem a temática, tornando impossível a obtenção de um consenso em relação à identidade, o nacionalismo e sua vinculação aos ideais de racismo e pureza culturas. Portanto, o que propomos aqui é um recorte. O que nos é permitido afirmar, sem reticências, é que o anunciado durante tanto tempo fim da "era do nacionalismo" está ainda bem distante de nossa realidade. (ANDERSON, 1993, p. 19).

Ernest Cassirer nos relata que em 1840, Thomas Carlyle iniciou suas conferências tratando sobre o tema que cem anos mais tarde seria a pedra de ordem da esfera terrestre. Carlyle propunha a ideia do "mito do herói” para estabelecer a ordem a e a submissão total dos cidadãos perante o seu Estado. O Estado-nação retomava a percepção que lembrava a autoridade divina da Idade Média, mas essa forma medieval de hierarquia era substituída por uma moderna forma de "herói-arquia" (CASSIRER, 2003, p. 228). Para ele não existia forma de coexistência em sociedade sem o desenvolvimento da ideia de heroísmo estatal e da identidade cultural como mecanismo de promoção da obediência passiva e da ordem" (CASSIRER, 2003, p. 230).

Muitos consideram as ideias de Carlyle como o gene principal dos regimes fascista e nazista do século $\mathrm{XX}$, mas esta percepção não lhe faz justiça, uma vez que nunca se admitiu o uso de mentiras como armas legítimas ou necessárias na sua teoria do heroísmo estatal. Ideia plenamente aderida pelo nacional-socialismo na Alemanha" (CASSIRER, 2003, p. 256).

É com Arthur de Gobineau que o culto do herói evolui para o culto da raça ${ }^{5}$. Uma das mais firmes convicções de Gobineau é a de que os seres humanos são subdivididos em raças com determinados graus de evolução e que apenas a raça branca tem vontade e o poder de edificar uma vida cultural plena”. As raças negras e amarelas não têm energia própria e devem ser impulsionadas pelas raças superiores. Sua tese possuía uma dimensão argumentativa tão simplória que causa estranhamento que

5 Cabe lembrar que o racismo também fora formulado a partir de prismas do pensamento evolucionista que marcavam a época como um todo, afetando diversas áreas científicas e inclusive sociais. tenha sido tão levada a sério e se tornado quase um lugar comum no fim do século XIX” (CASSIRER, 2003, p. 267).

A queda das civilizações se devia ao desvirtuamento da raça com a mistura de sangues. Assim sendo, qualquer mistura mantinha a preponderância da raça inferior. Aproximar-se do patamar de pureza seria um impeditivo para o iminente declínio da humanidade. Graças ao ideal racial se poderia pensar em uma espécie de "elite" configurada por uma "raça de príncipes", onde os mais aptos sobreviveriam aos dinamismos da contingência das misturas, para formar o tão sonhado mundo homogêneo, livre da diferença e da impureza (ARENDT, 1991, p. 203).

O racismo pressupõe a pureza cultural na teoria de Gobineau. Segundo ele: "todos os que se sentiam orgulhosos da sua linhagem e ascendência recusavam-se a misturar-se com o vulgo". A superioridade racial é realçada pela comparação das raças inferiores aos pés das superiores. Além disso, pensar os seres humanos como iguais universalmente, para ele, não passava de uma vulgaridade (CASSIRER, 2003, p. 267).

O termo "raça", para uma nova estruturação dos direitos humanos, perde sentido assim como a concepção de "identidade cultural". Admitir dicotomias raciais e identidades culturais é nos rendermos à redução do outro a um conceito, ou seja, que podemos explicar o outro a partir de sua nação; como se o pertencimento a uma nação eliminasse a singularidade de cada ser humana. Como se o conceito de "peruano", "inglês" ou "dinamarquês" reduzisse a termo o que vem a ser uma identidade.

O mesmo ocorre com a ideia de cidadania. Ao preconcebermos a atitude de alguém em virtude de sua condição de "estadunidense", "argentino" ou "brasileiro" estamos prestes a negar a sua idiossincrasia, a reduzir sua alteridade em nome de uma artificialidade imaginária e obliterar a sua diferença, pois, segundo a proposta da nova cosmopolítica, somos todos seres humanos integrantes de um e mesmo mundo.

As disseminações dos ideais de Estado-nação e identidade cultural foram (e ainda são) valiosos instru-

\footnotetext{
6 Para Adorno e Horkheimer "a raça não é imediatamente, como querem os racistas, uma característica natural particular. Ela é, antes, a redução ao natural, à pura violência, a particularidade obstinada que, no existente, é justamente o universal. A raça, hoje, é a auto-afirmação do indivíduo burguês integrado à coletividade bárbara"(ADORNO, 1985, p. 158).
} 
mentos de dominação. Segundo Cassirer (2003, p. 280), o que denominamos "nação" não é nunca um todo homogêneo, e sim um produto de misturas de sangue que não pode ser representado como uma totalidade; como se existisse um sentimento global vivenciado por todos os seres de uma dada comunidade.

Com a modernidade, observa-se uma transfiguração decisiva no próprio conceito de racismo ${ }^{7}$. Este deixa de ser um mero ódio entre determinados povos ou o símbolo de preconceitos religiosos, econômicos ou sociais e se torna uma doutrina política que instrumentaliza e justifica a implementação de uma política estatal violenta (DUARTE, 2008. p. 72.). Em outras palavras, podemos afirmar que o repúdio à diferença cultural é legitimado pelas democracias modernas quando estas, a título exemplificativo, tornam sem eficácia Tratados e Convenções internacionais em nome da soberania nacional (como vimos no exemplo dos apátridas e refugados anteriormente) bem como em outros exemplos como é o caso da diretiva de retorno, tema que permitimo-nos uma breve digressão antes de voltarmos à questão da identidade.

A diretiva foi desenvolvida na Europa para obstacularizar o trânsito de estrangeiros, facilitar a sua exclusão das nações européias e até criminalizar imigrantes bem como aqueles que os auxiliam, como é o caso visto na Espanha, onde, de acordo com o artigo 318 do código penal espanhol, que prevê uma pena de 8 anos de prisão para aqueles que conferem assistência para algum imigrante ilegal ou clandestino ${ }^{8}$.

A diretiva de retorno representa o posicionamento adotado pela comunidade européia em relação ao imigrante, a exemplo da proposta do governo Berlusconi, aprovada pelo parlamento italiano, segundo a qual a entrada e permanência ilegal na Itália seria punível como crime com pena de até 3 anos, obrigando, ainda, os fun-

\footnotetext{
7 "O racismo é impensável sem o avanço da ciência moderna, da tecnologia moderna e das formas modernas de poder estatal. Como tal, o racismo é estritamente um produto moderno. A modernidade tornou possível o racismo" (BAUMAN, 1998, p. 83).

8 É estratégia presente, a título exemplificativo, na França, quando adotou a política que ficou conhecida como "crime de hospitalidade" com a punição aos residentes franceses que acolhessem estrangeiros ilegais em sua morada. Mais sobre o tema, conferir: (PEREIRA, 2011). Sobre o tema, conferir também o tocante filme "Bem-Vindo" de Phhilipe Lioret, produzido em 2009.
}

cionários públicos a denunciarem imigrantes ilegais. A diretiva, aprovada pelo parlamento europeu em 16 de dezembro de 2009 (diretiva 2008/115 da comunidade européia), afirma que os estrangeiros serão tratados de forma humana e digna, respeitando princípios fundamentais do direito internacional.

Porém, os Estados contam com plena discricionariedade para aplicarem a cláusula de retorno, restando previsto, em seu ordenamento, um Centro de internamento de estrangeiros - CIE. O artigo 12 da diretiva prevê a possibilidade de prisão normal em casos excepcionais, caso o país não detenha centro de internamento. A prisão, segundo a diretiva é de 6 meses podendo ser renovada por mais 12 . Neste contexto, fica evidenciado que o sentimento de identidade nacional, gerado pela ficção da nacionalidade, pode se revelar como um expressivo instrumento para a xenofobia.

A experiência dos séculos nos mostra que a pior tirania é aquela exercida por meras ficções, mas o ser humano continua acreditando nesta espécie de "magia social", nesses mitos políticos "fabricados por artesões hábeis e matreiros" (CASSIRER, 2003, p. 327-327) ${ }^{9}$. CASSIRER problematiza a questão do patriotismo e se questiona: "o que vem a ser a ideia de país natal? É uma simples palavra a que não corresponde nenhuma realidade física ou histórica" do indivíduo. A pátria seria um termo "masculino" e "feminino" que unificaria, por si só, a simbologia dos termos "materno" e "paterno", os quais, nas suas entrelinhas, sugerem claramente a ideia de uma obediência incondicional, restaurando uma relação infantil dos adultos para com seu lar protetor (MORIN, 2005. p. 72).

Mas precisamos constantemente, segundo BAUMAN (2005, p. 90-92), de "histórias de identidade" em que digamos a nós "de onde viemos, quem somos e para onde vamos". Essas histórias são fundamentais para restaurar a "segurança", a partir de conservadorismo e de um exclusivismo da comunidade imaginária.

Isso não significa que se deva negar a própria cultura e sim compreender que os legados culturais detêm falhas (MORIN, 2005, p. 105), e por isso, julgar uma cultura a partir do próprio eixo de compreensão é o que podemos denominar de etnocentrismo. A percepção et-

\footnotetext{
9 No mesmo sentido, ARENDT (1991, p. 238) se posiciona: "As lendas sempre influenciaram fortemente a feitura da história."
} 
nocêntrica enseja uma visão de mundo onde apenas o que vale e importa é o que está em nosso próprio local de fala e o que a nossa própria cultura determina como valores, costumes e modelos aceitáveis de comportamento social (ROCHA, 1998, p. 7). Traz a tona a persistente classificação hierarquizante perante as diferentes sociedades humanas. Ingenuamente se esquece que, no patamar de civilização atual, todas as culturas são híbridas e interrelacionais.

É elucidativa a contribuição de Bhabha (2005, p. 24) nesta direção:

\begin{abstract}
Os próprios conceitos de culturas nacionais homogêneas, a transmissão consensual ou contínua de tradições históricas, ou comunidades étnicas "orgânicas", enquanto base do comparativismo cultural, estão em profundo processo de redefinição. O extremismo odioso do nacionalismo sérvio prova que a própria ideia de uma identidade nacional pura, etnicamente purificada", só pode ser atingida por meio da morte, literal e figurativa, dos complexos entrelaçamentos da história por meio das fronteiras culturalmente contingentes da nacionalidade moderna.
\end{abstract}

Intentemos demarcar aqui que, ao contextualizarmos a questão da identidade, articulando-a ao próprio desenvolvimento do racionalismo moderno, estamos querendo afirmar, provisoriamente, que as identidades são construídas, distribuídas, destruídas e reconstruídas nos processos de interações históricos e sociais. As identidades não resultam da extensão de um processo de identificação entre sujeito e Estado, tal qual pensado no berço do racionalismo moderno. As identidades são criadas em vista das nuances de diferenciação entre as culturas, por mais paradoxal que tal afirmação possa parecer. Só há identidade quando há o privilégio da diferença - do reconhecimento da diferença. Diferentes lugares e agentes, processos de diferenciação, conflitos sociais situacionais ou históricos, enfim uma intensa miscigenação social produz identidades que são ativadas estrategicamente. Entretanto, esse princípio estratégico constituiu o elemento dominante para explicar o fato de o conceito de identidade pretender-se uma construção estável, capaz de homogeneizar o espaço social, respondendo demandas de pertencimento. A diferença é aniquilada em nome de um suposto consenso. De uma suposta pureza identitária que sustenta a ideia de Estado-nação e muitas vezes sustenta discursos xenofóbicos e políticas de criminalização da cultura diferente.

\section{Interculturalismo como alternativa ao universalismo tradicional dos Direitos Humanos}

Muitos intelectuais acreditaram que a ênfase empreendida aos direitos humanos, após a segunda guerra mundial, traria o fim dos conflitos entre as minorias. A doutrina dos direitos humanos universais se apresentou como um substituto aos direitos das minorias e, a partir disso os membros destas não teriam necessidade (nem direito) de reivindicar por legislações especiais. A substituição de direitos específicos para grupos minoritários por direitos universais parecia uma evolução natural da humanidade que já não necessitaria mais adotar leis particulares para determinados grupos (KYMLICKA, 1995, p. 15)

Guiadas por essas diretrizes, as Nações Unidas, na Declaração Universal, negaram toda a referência aos direitos das minorias, pois elas desfrutam de igualdade de tratamento e, portanto, não têm legitimidade para exigir qualquer tipo de benefício que mantenha suas particularidades intactas ${ }^{10}$. Devem se adequar a um direito comum. Mas está claro que os direitos das minorias não podem submeter-se às categorias dos direitos humanos universais. Os procedimentos tradicionais vinculados à Declaração dos Direitos do Homem não são capazes de resolver importantes e controvertidas questões a esse respeito. Não que estes mecanismos dêem respostas equivocadas ao problema, mas sim porque não apresentam resposta alguma (KYMLICKA, 1995, p. 17-18).

A assim denominada por Morin (2005, p. 61) "cegueira ego-etnocentrica" não se desmaterializa com cartilhas universalistas de direitos humanos, mas com o interculturalismo de percepções sem a hegemonia de qualquer cultura. Desterritorializar a vontade fascista da "compreensão apropriativa" (SOUZA, 2005, p. 192) traz consigo a possibilidade de tornar assimilável o rosto de outrem, que não se contenta com meras boas intenções (LEVINAS, 1999, p. 238).

${ }^{10}$ Habermas (2007, p.171) percebe que o problema se mantém atual: "Mesmo dentro de uma comunidade republicana que garanta formalmente a igualdade de direitos para todos, pode eclodir um conflito cultural movido pelas minorias desprezadas contra a cultura da maioria. Exemplos recentes desse fenômeno são dados pela minoria de fala francesa no Canadá, pelos valões na Bélgica, pelos bascos e catalães na Espanha etc." 
Neste caso, seria preciso abandonar, por exemplo, a noção anacrônica de "raça", que é passível de desconstrução, seja pela visão científica robustecida pela descoberta do DNA, seja por concepções filosóficas que dinamizam esta ideia como algo que reduz a diferença à condição de mera inferioridade, na medida em que a "raça" designa uma condição de excentricidade em relação a um centro dominante e majoritário (DELEUZE; GUATARRI, 1997, p. 50). O termo "raça" só é atribuído a um rol de oprimidos, inexistindo a percepção de "raça dominante"11. Para Deleuze (2003, p. 300), a nossa racionalidade tende a ver aquilo que é diferente como fora do centro (ex-cêntrico) e este centro faz alusão ao nosso próprio eixo de compreensão. A visão do "outro" tende a considerar sua relação com o "centro" e nunca como uma outra possibilidade fora deste perímetro determinado. Como meramente outra. Como algo situado nas bordas. Na periferia. Na beira.

Se a relação é fundada não mais a partir da semelhança, mas da diferença, torna-se possível, pelo contraste, reconhecer a condição que situa cada um em sua própria diferença. Essa distância se torna o elemento fundamental da igualdade entre os homens.

Quanto maior o respeito da exceção e da diferença, mais igualitária a sociedade será, por mais paradoxal que essa frase possa parecer (GAUER, 2005, p. 402) ${ }^{12}$. Pois quando percebo a diferença de outro, possibilito-me perceber a mim mesmo como diferente, pelo contraste ${ }^{13}$.

Como bem preleciona ARENDT (2004, p. 16): “A pluralidade é a condição da ação humana pelo fato de sermos todos os mesmos, isto é, humanos, sem que nin-

\footnotetext{
11 "uma raça não se define por sua pureza, mas, ao contrário, pela impureza que um sistema de dominação lhe confere. Bastardo e mestiço são os verdadeiros nomes de raça" (DELEUZE; GUATARRI, 1997, p. 50).

${ }^{12}$ Neste sentido, Gauer (2005, p. 42), ao comentar a obra "pureza e perigo", de Mary Douglas, a autora invoca a necessidade de reconhecer a exceção como mecanismo de resistência à ausência de laços solidários da sociedade contemporânea. Consagra-se, assim, a aversão a impulsões globalizantes e soberanas, e explicações positivistas/ racionalistas corrompidas pelo ideal de perseguição ao "sujo" e ao "impuro".

${ }^{13}$ Literalmente, Damatta (1997, p. 24) afirma que "apesar das diferenças e por causa delas, nós sempre nos reconhecemos nos outros e eu estou inclinado a acreditar que a distância é o elemento fundamental na percepção da igualdade entre os homens. Deste modo, quando vejo um costume diferente é que acabo reconhecendo, pelo contraste, meu próprio costume".
}

guém seja exatamente igual a qualquer pessoa que tenha existido, exista ou venha a existir". A igualdade tanto em direitos como em dignidade, é condição básica de uma sociedade plural, mas, além disso, somente com a "não indiferença ao que me é absolutamente diferente" (LEVINAS, 1997, p. 176), sem o rótulo de "anormal" ou "fora dos padrões", nas próprias acepções pejorativas dos termos, ou seja, sendo outrem naturalmente compreendido como um "não-igual-a-mim", é que os direitos humanos, finalmente, alcançarão o seu sentido almejado.

A resposta do mundo, ou dos que podemos chamar de representantes do mundo - tidos como símbolos de progresso e humanidade, na incumbência de reprimir a diretriz purificadora e xenofóbica advinda do nazi-fascismo e dos demais regimes autocráticos da época, está contida na declaração de Direitos Humanos de 1948. A declaração de 1948, reiterada pela Declaração de Direitos Humanos de Viena de 1993, segundo Piovesan (1997, p. 131), representa a consolidação do movimento de internacionalização dos direitos humanos.

Entretanto, esta tentativa não conseguiu abarcar de forma satisfatória a gama de complexidades nos problemas da humanidade, pois ela ainda representa uma percepção totalizante de compreensão dos direitos humanos. $\mathrm{O}$ universalismo dos direitos humanos lança mão da igualdade como ponto central de seu argumento, mas esquece que a diferença que é a condição formadora do ser humano como humano, como aqui teimamos em reiterar. O resultado foi a agregação dos homens a um mesmo patamar de igualdade, lesando aqueles que se auto compreendem como minorias em razão de sua assimetria ao padrão igualitário instituído.

A proposta de Boaventura de Sousa Santos é a consolidação de uma hermenêutica diatópica, que visa superar as visões universalistas e relativistas em relação ao problema da igualdade. Parte da premissa de que todas as culturas, por mais força que demonstrem, são incompletas e problemáticas no que tange à consolidação das garantias fundamentais e suas implementações políticas (SANTOS, 2003, p. 441 ss.). Para se concretizar este pensamento progressista deve-se expandir a consciência de incompletude cultural que permeia a racionalidade de cada civilização, pois a reversibilidade do diálogo é fundamental para impedir a perversão e subversão desta conquista e transformá-la em um fechamento cultural recíproco. Além disso, a emancipação da discussão con- 
tribuirá para se distinguir a luta pela igualdade e a luta pelo reconhecimento igualitário das diferenças, onde ambas poderão atuar de forma eficaz (SANTOS, 2003, p. 443-455).

Pressupõe-se assim o entrelaçamento do princípio da igualdade com o princípio do reconhecimento da diferença. Nas palavras de SANTOS (2003, p. 458): "temos o direito de ser iguais quando a diferença nos inferioriza; temos o direito de ser diferentes quando a igualdade nos descaracteriza”.

Uma nova perspectiva, contextualizada com o interculturalismo, pressupõe uma interpretação para além do multiculturalismo tradicional. Segundo Bhabha (2005, p. 27), não se trata mais de dividir o centro da periferia, a maioria da minoria, mas sim uma posição que comporte o hibridismo cultural sem hierarquias supostas ou impostas. Porque a minoria não deseja a possibilidade de ser incluída como outrora. Ela deseja ser reconhecida não como minoria, pois admitir a ideia de minoria reforça seu locus de periferia. O reconhecimento se dá na sua própria diferença (GAUER, 2004. p. 234-235). Encontrar esse entre-lugar é "tocar o futuro em seu lado de cá" (BHABHA, 2005, p. 27) e reconhecer a necessária articulação do hibridismo da cultura como formulação do olhar da diferença.

Bauman (2005, p. 82-85) nos mostra que é um costume designar o rótulo de "minoria étnica" para determinadas pessoas sem que lhes seja pedido qualquer consentimento. A postura construtora da "nação" se reproduz pela negação da diversidade. O liberalismo cultural traduz-se na ideia de nacionalidade compartilhada, mas na prática, ela significa a rendição da cultura minoritária em nome da cultura majoritária, demonstrando que apesar de terem diferentes estratégias, o nacionalismo e o liberalismo compartilham o mesmo propósito, pois a primeira aponta para a aniquilação da diferença enquanto a segunda aponta para a aniquilação do diferente.

Segundo Derrida (2004, p. 136-137):

Todos os nacionalismos pretendem ser exemplarmente universais, cada um alega essa exemplaridade e pretende ser mais do que um nacionalismo a mais. Mesmo se, de fato, parece difícil manter uma fé na eleição, e sobretudo na eleição de um povo eterno, ao abrigo de toda tentação "nacionalista", mesmo se parece difícil dissociá-las na efetividade política de todo Estado-nação.
Não estamos aqui afirmando que o nacionalismo seja propriamente confundido com o racismo ou com a aversão ao outro. Anderson (1993, p. 200 ss), neste sentido, faz o contraponto alertando que o nacionalismo pode inspirar amor e empatia, visualizáveis na música, poesia, artes plásticas e na literatura de diversas culturas ${ }^{14}$. Nosso interesse é demonstrar que um saudável sentimento de pertencimento e identificação nacional pode se tornar em uma reação de exclusão e aversão à diferença intercultural.

Os governos liberais, em sua maioria, ao longo da história, empregam uma postura avessa às propostas interculturais. Em busca de uma organização societária homogênea, as políticas utilizadas pelos Estados liberais eliminaram fisicamente algumas minorias culturais através de expulsões maciças (algo que ficou caracterizado como "limpeza étnica") e, perante outras minorias, forçaram-nas a adotar a língua, a religião e os costumes da maioria, além de submetê-las a uma segregação física, assim como a privação de direitos políticos. (KYMLICKA, 1995, p. 14). Isso é dado como própria forma de organização e funcionamento do Estado nacional, sendo um dos elementos que deve orientar renovadas perspectivas na reflexão e pesquisa sobre direitos humanos.

Um exemplo que ilustra bem esta estratégia da cultura da exclusão está nas políticas francesas desenvolvidas para tratar os estrangeiros em seu território. Em 2010, o governo francês, liderado pelo presidente Nicolas Sarkozy, alegando que a legislação sobre imigração precisava de ajustes, propôs retirar a nacionalidade de estrangeiros naturalizados que agredissem a polícia ou pessoas com "autoridade pública". Outro tema muito discutido pelas comunidades internacionais foi a medida tomada como política de segurança francesa, que cunhou a repatriação de inúmeros ciganos da etnia rom, promovendo seu retorno a Romênia e Bulgária.

A política francesa para estrangeiros há tempos demonstra características de repressão à diferença. Em

\footnotetext{
${ }^{14}$ Para o autor, trata-se de um equívoco relacionar o nacionalismo ao racismo, pois o nacionalismo está atrelado a circunstâncias históricas enquanto o racismo advém de uma dimensão natural. Nas palavras de Anderson (1993, p. 210) “el nacionalismo piensa em términos de los destinos históricos, mientras que el racismo sueña con contaminaciones eternas, transmitidas desde el princípio de los tiempos mediante uma sucesion interminable de cópulas asquerosas: fuera de la história”.
} 
2007, foi determinado que os estrangeiros que entrassem na França precisariam assinar um contrato reconhecendo a proibição do uso de véu islâmico. Tais demonstrações de insensibilidade com as diferenças denotam a necessidade de um reconhecimento cultural em lugar da instrumentalização cultural.

Flores (2000, p. 11-13) relata a necessidade de uma nova compreensão dos direitos humanos para além de pactos e convenções, e propõe a sua crítica no intento de recuperar a ação política das pessoas, formular uma filosofia impura de garantias fundamentais e desconstruir o absolutismo de verdades cominado pelo universalismo tradicional.

O rompimento com este paradigma será desenvolvido somente a partir de uma metodologia que admita como válido todos os pontos de vistas possíveis referentes ao tema. Isto é o que Herrera Flores pretende com o que chamou de "relativismo relacional" como paradigma para compreender e interpretar o contexto de conflitos do período moderno e a crise das garantias fundamentais.

Segundo Flores (2000, p. 32), o universalismo que temos hoje, ao invés de ser o ponto de chegada como se acredita, seria um mero ponto de partida para alavancar uma discussão que reconheça o pluralismo de concepções sobre os direitos humanos. Segundo o autor, há duas principais visões atuais sobre a interpretação dos direitos humanos. Em uma delas, denominada pelo autor como visão abstrata, reverenciada pela maioria dos pensadores ocidentais, impera a racionalidade formal a partir de práticas universalistas, que acabam manifestando um conteúdo vazio pela sua ineficácia e inaplicabilidade. A outra, tida como visão localista valoriza a diferença entre os humanos e propõe ações particulares para garantir a igualdade perante a hipossuficiência da alteridade minoritária (FLORES, 2000, p. 48).

Ambas propostas apresentam pontos positivos e detêm fundamentos para serem defendidos. Mas o problema surge quando cada uma delas aceita unicamente os seus postulados como válidos e considera inferiores os propostos pela outra. Com isso, é relevante construir uma cultura que acolha a ideia de universalidade das garantias e a do respeito às diferenças, isto é, uma visão complexa que atue em torno do problema, proporcionando uma análise que acompanhe o dinamismo e as constantes movimentações do mundo, abandonado o entendimento deste como ente de relações inertes (FLORES, 2000, p. 63).

A visão complexa postula uma racionalidade de resistência que iniba os determinismos dos universalistas tradicionais e que seja adepta a uma prática intercultural de relações híbridas e comprometidas em dar vazão à singularidade e a luta pelo reconhecimento da diferença. Não se pode desmembrar os direitos humanos em categoriais "individuais", "coletivas", "econômicas" e "culturais" ou dividi-lo em gerações, pois somente há uma classe de direitos para todos. A luta pelos direitos é de caráter global e não pode ser multifacetada em parcelas.

Boaventura de Souza Santos também critica tais concepções de direitos humanos e revela que seu universalismo tende a operar como um localismo globalizado, caracterizando-se como uma forma de globalização hegemônica dando vazão ao "choque de civilizações" (SANTOS, 2003, p. 438). A Declaração Universal de 1948 não contou com a maioria dos povos do mundo na sua elaboração e está contaminada com uma forma muito simplista e mecanicista no que entende por direitos e deveres, ou seja, apenas garante direitos àqueles dos quais pode exigir deveres ${ }^{15}$. A cultura ocidental estabelece demasiadas dicotomias entre o indivíduo e a sociedade e, com isso, torna os direitos humanos vulneráveis a um individualismo possessivo, alienado e narcisista. Esta concepção liberal de direitos humanos dá prioridade apenas a direitos cívicos e políticos, por isso o autor em tela privilegia a versão social-democrata de direitos humanos, porque esta estende seu campo de atividade até perspectivas econômicas e sociais (SANTOS, 2003, p. 447-456).

A percepção de Piovesan (2008, p. 11-13), contribui para o debate. Para ela, guiada por Boaventura, a discussão entre universalismo e relativismo dos direitos humanos deve dar espaço a uma transformação cosmopolita dos direitos humanos, onde uma cultura poderia intervir na outra, formando assim uma interculturalidade que observe um "mínimo ético irredutível", flexibilizando, assim, a concepção universalista tradicional e dando espaço a um universalismo de confluência.

\footnotetext{
${ }^{15}$ Essa afirmação explica porque a concepção ocidental dos direitos humanos não confere direitos à natureza, pois não lhe pode impor deveres. Conforme Santos (2003, p. 439-446).
} 
Derrida (2003, p. 142) compreende os direitos humanos como, de algum modo, uma conquista fundamental e necessária para a consolidação de uma conjuntura cosmopolítica, apesar de sempre problematizar seus limites a partir de sua ideia de "democracia por vir", temática que trabalhamos mais detalhadamente em outro lugar (PEREIRA, 2011). Para ele, "é preciso mais do que nunca ficar ao lado dos direitos humanos [...] precisamos deles e eles são precisos, pois há sempre uma carência, uma falta, uma penúria, uma insuficiência; os direitos humanos jamais são suficientes. O que já é o bastante para nos lembrar que eles não são naturais. Possuem uma história - uma história recente, complexa e inacabada".

\section{Conclusão}

O objetivo deste artigo foi discutir a insuficiência da concepção tradicional de direitos humanos no que tange aos apátridas e refugiados. Procuramos demonstrar como culto a "nacionalidade" representa um obstáculo para a concretização dos direitos. Em verdade, o culto a "nacionalidade", muitas vezes ancorado pelo sentimento patriótico, simboliza a indiferença e o ódio em relação a uma cultura diversa. Em outras palavras, significa um empecilho para aquele que vem de fora da minha pátria ser recepcionado como um ser humano detentor de direitos, independente de sua nacionalidade.

Nesse sentido, tentou-se demonstrar que a concretização dos direitos humanos reivindica um novo modelo de fundamentação, que suporte e reconheça a diferença, pois nada mais diferente de mim do que aquele que vem de fora, que não fala minha língua e que não compartilha da minha cultura.

A recepção da cultura diversa, do costume diferente, representada aqui pelos apátridas e refugiados, significa um transpassar do modelo tradicional de direitos humanos, refém e ao mesmo tempo mantenedor do culto à nacionalidade, quando reconhece maiores privilégios àquele que tem pátria, como se a pátria não fosse uma criação artificial criada pelo ser humano.

Para transpassarmos esse modelo, é necessária uma reinvenção do estatuto de cidadania, reconhecendo desde já o ideário cosmopolita de forma radical e não apenas como um adorno retórico muitas vezes utilizado nos discursos que permeiam os discursos acadêmicos das
Relações Internacionais e do Direito Internacional. Falar em cosmopolitismo significa levar a sério a ficção da nacionalidade e do estatuto de cidadania, pois no mesmo instante onde se criou a figura do cidadão, criou-se a figura do não-cidadão - aquele que não tem pátria e, logo, não tem direitos.

A reinvenção da cidadania, de algum modo significa até mesmo negar a ideia de cidadania, para se obter uma dimensão cosmopolita a partir de uma solidariedade internacional na qual nenhum Estado, partido, sindicato ou organização de cidadãos se incumbe verdadeiramente. Um cosmopolitismo ainda não pensado pelos teóricos cosmopolitas, pois o cosmopolitismo tradicional "ainda supõe a instância do Estado e do cidadão, ainda que seja cidadão do mundo" (DERRIDA, 2004, p. 317-318). E o passo para isso seria o pensamento da hospitalidade ${ }^{16}$.

Derrida (2003, p. 69) traduz a lei da hospitalidade como uma lei incondicional e ilimitada, como o oferecimento do lar a quem chega de fora, ao estrangeiro da subjetividade. Mais que isso; a lei da hospitalidade oferece a si própria, o seu próprio si, "sem pedir a ele nem seu nome, nem contrapartida, nem preencher a mínima condição". A lei da hospitalidade está em contraponto às leis da hospitalidade, que se dirigem a direitos e deveres sempre condicionados e condicionais, como tratam os Tratados e Convenções Internacionais sobre o tema dos apátridas e refugiados explorados no início do artigo.

Já a lei da hospitalidade se concentra em pensar o político para além do político, a partir de uma nova internacionalidade; a partir de um cosmopolitismo reinventado. Um cosmopolitismo para além do cosmopolitismo político pensado pelo ideário iluminista, pois este cosmopolitismo está condicionando pela soberania do Estado. Está estruturado pelos limites jurídico-políticos. E este cosmopolitismo jurídico, guiado pelas leis da hospitalidade condicional, revelou-se e revela-se incapaz de responder às inúmera situações de violência pelas quais se submetem os apátridas, para além do clássico e habitual esquema do repatriamento ou da integração - naturalização (BERNARDO, 2002, p. 437).

\footnotetext{
${ }^{16}$ Aqui não teremos espaço para discorrer mais detidamente sobre a hospitalidade como nova proposta de sentido para as relações internacionais. Remetemos o leitor para nossa obra "A pátria dos sem pátria: direitos humanos \& alteridade" (PEREIRA, 2011).
} 
O universalismo dos direitos humanos visto de forma tradicional, quando se depara com o choque cultural proporcionados por costumes diversos dos costumes hegemônicos, também não oferece a necessária radicalidade para enfrentar os problemas que envolvem os apátridas e refugiados no panorama mundial atual. Em virtude disso, rompemos definitivamente com a premissa universalista dos direitos humanos.

A única premissa universal que se pode admitir é que todas as pessoas devem ter a possibilidade de lutar por ter sua singularidade reconhecida, não mais envolta em essencialismos. Assim, legitima-se a busca dos apátridas e refugiados pelo reconhecimento de sua diferença.

\section{Referências}

ADORNO, Theodor; HORKHEIMER, Max. Dialética do esclarecimento. Rio de Janeiro: J. Zahar editor, 1985.

ALMEIDA, Guilherme Assis de. Direitos Humanos e nãoviolência. São Paulo: Atlas, 2001.

ANDERSON, Benedict. Comunidades imaginadas: reflexiones sobre el origen y la difusión del nacionalismo. México: Fondo de cultura econômica, 1993.

ARENDT, Hannah. Origens do totalitarismo. São Paulo: Companhia das letras, 1991.

ARENDT, Hannah. A condição humana. Rio de Janeiro: Forense Universitária, 2004.

BAUMAN, Zygmunt. Modernidade e holocausto. Rio de Janeiro: J. Zahar editor, 1998.

BAUMAN, Zygmunt. Comunidade: a busca por segurança no mundo atual. Rio de Janeiro: J. Zahar editor, 2005.

BENJAMIN, Walter. Obras escolhidas: magia e técnica, arte e política. São Paulo: Brasiliense, 1996.

BERNARDO, Fernanda. A ética da hospitalidade, segundo J. Derrida, ou o porvir do cosmopolitismo por vir a propósito das cidades-refúgio, re-inventar a cidadania. Revista Filosófica de Coimbra, Coimbra-Portugal, n. 22, p. 421-446, 2002.

BHABHA, Homi K. O local da cultura. Belo Horizonte: UFMG, 2005.

TRINDADE, Antônio Augusto Trindade. Princípios de direito internacional contemporâneo. Brasília: UNB, 1981.
CASSIRER, Ernst. O mito do Estado. São Paulo: Códex, 2003.

DAMATTA, Roberto. Relativizando: uma introdução à antropologia social. Rio de Janeiro: Rocco, 1997.

DELEUZE, Gilles. Diferença e repetição. São Paulo: Editora paz e terra, 2006.

DELEUZE, Gilles; GUATTARI, Felix. Mil platôs: capitalismo e esquizofrenia. São Paulo: Editora 34, 1996. v. 5.

DERRIDA, Jacques. Adeus a Emmanuel Levinas. São Paulo: Perspectiva, 2004.

DERRIDA, Jacques. Papel-máquina. São Paulo: Estação liberdade, 2004.

DERRIDA, Jacques. Anne Dufourmantelle convida Jacques Derrida a falar da hospitalidade. São Paulo: Escuta, 2003.

DERRIDA, Jacques. Espectros de Marx: Estado da dívida, o trabalho do luto e a nova Internacional. Rio de Janeiro: Relume, 1994.

DERRIDA, Jacques. Filosofia em tempo de terror. In: BORRADORI, Giovanna (Org.). Diálogos com Habermas e Derrida. Rio de Janeiro: J. Zahar editor, 2003.

DUARTE, André. De Michel Foucault a Giorgio Agamben: a trajetória do conceito de biopolítica. In: SOUZA, Ricardo Timm de; OLIVEIRA, Nythamar Fernandes. Fenomenologia hoje III, bioética, biotecnologia, biopolítica. Porto Alegre: Edipucrs, 2008.

FERRIS, Elizabeth G. The role of non-governmental organizations in the international refugee regime. In: STEIMER; Niklaus; GIBNEY, Mark; LOESCHER, Gil (Ed.). Problems of protection: the UNHCR, refugees and human rights. London: Routledge, 2003.

FLORES, Joaquim Herrera. El vuelo de Anteo. Derechos Humanos y crítica a la razón liberal. Bilbao: Desclée de Brouwer, 2000.

GAUER, Ruth M. Chittó. Da diferença perigosa ao perigo da igualdade. Reflexões em torno do paradoxo moderno, Civitas, Porto Alegre, v. 5, n. 2, p. 399-413, jul./dez. 2005.

GAUER, Ruth M. Chittó. Interrogando o limite entre historicidade e identidade. In: GAUER, Ruth M. Chittó (Org.). A qualidade do tempo: para além das aparências históricas. Rio de Janeiro: Lúmen Júris, 2004.

HABERMAS, Jürgen. A inclusão do outro: estudos de teoria política. São Paulo: Edições Loyola. 2007. 
JUBILUT, Liliana Lyra. O direito internacional dos refugiados e sua aplicação no ordenamento jurídico brasileiro. São Paulo: Método, 2007.

KYMLICKA, Will. Ciudadania multicultural: una teoría liberal de los derechos de lãs minorias. Barcelona: Paídos, 1995.

LÉVINAS, Emmanuel. Entre nós: ensaios sobre a alteridade. Petrópolis: vozes, 1997.

LÉVINAS, Emmanuel. Totalidad y infinito: ensayo sobre La exterioridad. Salamanca: Sígueme, 1999.

MORIN, Edgar. Terra pátria. Porto Alegre: Sulina, 2005.

PEREIRA, Gustavo Oliveira de Lima. A pátria dos sem pátria: direitos humanos \& alteridade. Porto Alegre: Uniritter, 2011.

PIOVESAN, Flávia. Direitos humanos e o direito constitucional internacional. São Paulo: Max Limonad, 1997.
PIOVESAN, Flávia. Concepção contemporânea de Direitos Humanos: desafios e perspectivas. In: ROCHA, João Carlos de C.; HENRIQUES FILHO, Tarcísio H.; CAZETTA, Ubiratan (Coord). Direitos humanos: desafios comunitários contemporâneos: 10 anos do estatuto dos refugiados (Lei n.9.474 de 22 de julho de 1997). Belo Horizonte: DelRey, 2008

ROCHA, Everaldo P. Guimarães. O que é etnocentrismo. Brasília: Brasiliense, 1998.

SANTOS, Boaventura de Souza. Reconhecer para liberta: os caminhos do cosmopolitismo multicultural. Rio de Janeiro: Civilização Brasileira, 2003.

SOUZA, Ricardo Timm de. Sentido e alteridade. Dez ensaios sobre o pensamento de Emmanuel Levinas. Porto Alegre: EDIPUCRS, 2005. Coleção filosofia, n. 120. 